2

3

4

\section{A novel and versatile flash-freezing approach for evaluating the health of Delta Smelt} 2

3 Authors: Swee J. Teh*, Dolores V. Baxa, Bruce G. Hammock, Saikrithika A Gandhi, Tomofumi

4 Kurobe

5

8 Aquatic Health Program, School of Veterinary Medicine, Department of Anatomy, Physiology, 9 and Cell Biology, One Shields Avenue, University of California, Davis, California 95616, USA 10 11

$12 *$ *Corresponding author email: sjteh@ucdavis.edu

(C) 2015. This manuscript version is made available under the Elsevier user license http://www.elsevier.com/open-access/userlicense/1.0/ 
15 A common approach used to assess environmental impacts in aquatic environments is to measure 16 indicators of stress (biomarkers) and condition of fish within ecosystems. Particularly in 17 estuarine ecosystems with multiple stressors, it is often desirable to quantify a suite of biological 18 endpoints that 1) reflect fish condition at several levels of biological organization and time scales and 2) are sensitive to a range of environmental stressors. However, established methods of preservation and processing of fish for specific endpoints are often incompatible. Here, we developed a novel flash-freezing approach for assessing the health of a small, sensitive fish, the endangered Delta Smelt (Hypomesus transpacificus) after collections from the San Francisco Estuary (SFE). We assess whether flash-freezing the entire fish ensures effective preservation of multiple tissues for subsequent biomarker analyses by comparing measurements of fresh to frozen tissue. Tissues included brain, gill, and liver for enzyme activity, kidney and spleen for pathogens, and gills, liver, and gonads for histopathology and reproduction. Although flashfreezing in liquid nitrogen altered the length, weight, and condition factor of Delta Smelt, the percent changes were small $(<1.5 \%)$. Histological analyses of the cellular morphology of gills, liver, and gonads were similar between both methods. Freezing artefacts were observed in ovaries, but did not hinder the identification and interpretation of cell types and oocyte stages. Freezing did not alter bacterial isolation or the activities of ethoxyresorufin-0-deethylase (EROD) or acetylcholinesterase (AChE), but had a small, negative influence on sodium potassium adenosine triphosphatase (ATPase) activity. Thus, flash-freezing in the field is a versatile preservation method for Delta Smelt, allowing for multiple tissue collections and bioassays from an individual tiny fish exposed to a wide range of natural and anthropogenic stressors. Similar methodology may be applicable to other species for which a range of biological endpoints and histopathology data are needed.

Keywords: Flash-freezing, Necropsy, Biomarker, Delta Smelt, San Francisco Estuary 


\section{Introduction}

In the past few decades, researchers have generally used the condition of a piscivorous fish as an indicator of aquatic ecosystem health. Typically, these species are of economic importance, easily collected, and relatively tolerant to a wide range of natural and anthropogenic stressors. The driving force for initiating most fish condition assessments is often related to water quality impairment caused by contaminants from chronic pollution or impacts of catastrophic events. For example, Bevelhimer et al. (2014) utilized a wide range of physiological and energetic responses to evaluate the health of fishes near a coal ash spill in east Tennessee. Similarly, Adams et al. (1996) used a suite of biological endpoints to evaluate the health and condition of wild fish in the Pigeon River, Tennessee that received bleached kraft mill effluent (Adams et al., 1996). In the Clinch River/Watts Barr Reservoir, Adams et al. (1999) quantified the enzymatic, reproductive, and histopathological response of fish to contaminant loading, primarily mercury and PCBs, in the Clinch River/Watts Bar Reservoir system. In other cases, fish health assessments may also aim to address factors associated with the onset and development of disease and reproductive abnormality in natural fish populations (e.g., Pierce et al., 1978; Myers et al., 1998; Johnson et al., 1998).

In estuarine ecosystems, where a wider range of potential stressors exist, a broader approach may be needed to assess organism or ecosystem condition. Estuaries are naturally variable in terms of physicochemical (e.g., salinity and temperature) and biological (e.g., algal blooms) conditions, adding complexity to any condition assessment. Although using a suite of biomarkers at several levels of biological organization has been proposed as a weight-of-evidence method to assess estuarine organism and ecosystem health (Adams et al., 1989; Huggett et al., 1992), a comprehensive health assessment is impossible with standard preservation methods. Here, we describe an approach for assessing the condition of the Delta Smelt (Hypomesus transpacificus), a small (adults 60-80 mm, standard length) estuarine fish endemic to fresh and brackish water habitats in the San Francisco Estuary (SFE). The SFE is formed by the convergence of the Sacramento and San Joaquin Rivers and the Pacific Ocean (Moyle et al., 1992; Moyle, 2002). The abundance of Delta Smelt has been in decline for decades, leading to the listing of the species as threatened and endangered under the Federal and California State Threatened and Endangered Species Acts, respectively (USFWS 1993, CDFW 2014). The SFE is highly altered by a wide range of temporally and spatially covarying 
72 anthropogenic impacts. Therefore, a comprehensive condition assessment must be sensitive to

73 many potential stressors, including poor nutrition, contaminants, disease, and changing

74 physicochemical conditions. In addition, Delta Smelt is notoriously sensitive (Moyle et al., 75 1992), so an effective and rapid preservation method is essential to minimize artefacts caused by 76 sampling stress. Importantly, the threatened and endangered status of the Delta Smelt requires 77 mandatory restrictions on all collections, hence the data gathered from each individual must be 78 maximized.

79 To address these issues, we developed a method in which Delta Smelt collected in the field are frozen in liquid nitrogen immediately following capture. Then, using staggered, rapid necropsies of fish as they defrost in the laboratory, multiple tissues are processed for measurement of a large suite of biological endpoints. These endpoints include general body and organ condition indices, nutritional indicators, otolith aging and microchemistry, enzymatic markers of exposure, pathogens, histopathologic markers, and reproductive endpoints. However, enzymatic, microbiological, histopathological and reproductive indices are traditionally evaluated using fresh samples. Accordingly, the purpose of this paper is threefold: 1) explain the relevance of flash-freezing for preserving smelt and use in various biomarkers at multiple levels of biological organization, 2) describe the method, and 3) evaluate the compatibility of flashfrozen tissues with endpoints routinely assessed by conventional techniques. For the latter, flashfrozen tissues were evaluated in parallel with fresh tissues to determine the diagnostic accuracy and validity of the non-conventional flash-freezing method.

\section{Materials and methods 2.1. Comparison of conventional and flash-freezing methods}

Adult Delta Smelt from the Fish Conservation and Culture Laboratory (FCCL) in Tracy, California were used for comparison of endpoints from fresh and flash-frozen tissues. The fish were transported live to the Aquatic Health Program at UC Davis, California. The influence of flash-freezing was evaluated using 95 fish: 10 for morphometry, 10 for enzyme activity (gill, liver, and brain), 10 for pathogens (spleen and kidney), 60 for histology (gill, liver, and gonad), and 5 for oocytes (size and internal structure).

For morphometry, enzyme, and pathogen endpoints as described below, groups of fish (numbers are indicated above) were processed where for each fish, one portion of tissue is fresh and a corresponding portion is flash-frozen. All endpoints including histology were performed 
and analyzed independently as needed and as described below. In this context, the results for each endpoint from each fish must be only attributed to the differences between fresh and frozen tissues to determine the compatibility of flash freezing to methods that traditionally use fresh samples (i.e., morphometry, enzyme, pathogen, histology).

In cases for which a significant effect of freezing was found, we used simple linear regression to develop a relationship between fresh and frozen measurements.

\subsection{Morphometric analysis}

Individual Delta Smelt ( $\mathrm{n}=10)$ was pithed, blotted dry gently on paper towels, measured

\subsection{Enzyme analysis}

Enzyme activity was compared between fresh and flash-frozen brain, gill, and liver of Delta Smelt $(n=10)$. The fish were pithed, the tissues were excised, and each organ was cut into 2 portions. One portion of each organ was analyzed immediately (without freezing) for enzyme activity. The second portion was kept in a microcentrifuge tube and flash-frozen in liquid nitrogen and stored in $\mathrm{a}-80^{\circ} \mathrm{C}$ freezer for one week before conducting the analysis. The brain was analyzed for acetylcholinesterase $(\mathrm{AChE}, \mathrm{n}=10)$, the liver for ethoxyresorufin-0-deethylase (EROD, $n=10$ ), and the gills for sodium potassium adenosine triphosphatase (ATPase) activity ( $\mathrm{n}=9$; gill tissue from one fish was accidentally lost). All of the enzymatic assays followed published methods with minor modifications: AChE (Ellman et al., 1961), EROD (Eggens and Galgani, 1992; Burke and Mayer, 1974), and ATPase (Holliday, 1985). The enzymatic activities were normalized to protein concentration in soluble fraction using the Lowry protein assay (Lowry et al., 1951) prior to determination of enzyme levels. Statistical differences in enzymatic activities were compared between fresh and flash-frozen tissues using paired t-tests. 


\subsection{Bacterial and viral isolation}

Isolation of bacteria and viruses were compared between fresh and frozen tissue using pooled spleen and kidney from individual Delta Smelt $(n=10)$. Tissues were processed as follows: the kidney and spleen were excised from each fish, pooled, suspended in $350 \mu \mathrm{l}$ Minimum Essential Medium Eagle (MEM, Sigma Aldrich) in a microfuge tube, and homogenized for 1 min using a sterile pellet pestle (Kimble-Chase Kontes, Fishewr Scientific). After thorough mixing, a $50 \mu$ homogenate (fresh sample, conventional method) was inoculated onto each of the three culture plates as indicated below. The remaining half of each homogenate of pooled tissue was stored in liquid nitrogen for 7 days (freezing method). Frozen samples were thawed on ice prior to inoculation onto each medium.

For bacterial isolation, subsamples of the fresh or frozen homogenate were inoculated (ca. $20 \mu \mathrm{l} /$ plate) onto three separate culture plates: Blood agar for general bacterial isolation, Tryptone Yeast Extract Salt (TYES) for fastidious flexibacteria, and Middlebrook 7H10 agar (Difco) for mycobacteria. The plates were incubated at $15^{\circ} \mathrm{C}$ for 7 days and examined for bacterial growth. Bacterial isolation followed standard procedures (AFS - Fish Health Section, 2007). The severity of anomaly was assessed according to Goede and Barton (1990) where values were assigned (0-4) based on the number and identity of colonies that grew on plates, referred to as "pathogen score": $0=$ zero colonies, $1=1-10$ colonies, $2=11-20$ colonies, $3=$ 21-200 colonies, and $4 \geq 201$ colonies. After bacterial inoculation, the supernatant from the remaining homogenate from each of the fish was used for virus isolation by tissue culture following standard methods (AFS - Fish Health Section, 2007).

Colonies on Blood agar, TYES, and MiddleBrook 7H10 agar were examined for basic morphologic and biochemical characteristics (AFS - Fish Health Section 2007). Dominant bacterial isolates were identified presumptively by phenotypic characterization and verified by sequencing using the 16S ribosomal RNA (rRNA) gene (Cunningham, 2002). The universal bacterial primers EUBA/ EUBB were used for PCR to amplify the 16S ribosomal DNA (rDNA) regions. The amplified products were submitted to Davis Sequencing Inc. (http://www.davissequencing.com/index.htm) to determine the DNA sequences of representative isolates and then compared to known sequences in the GenBank database. 
For virus isolation, cell lines including EPC (Epithelioma papulosum Cyprinid carp), CHSE- 214 (Chinook Salmon Embryo), and BF2 (Bluegill Fry) were inoculated with each supernatant sample. In addition, specific cell lines that we developed from Delta Smelt gills and threadfin shad gills following standard methods (AFS - Fish Health Section, 2007) were also used for virus isolation. Cell cultures were incubated at $15^{\circ} \mathrm{C}$ for a minimum of 21 days and sub cultured within 14 days.

\subsection{Histological analysis}

Adult Delta Smelt ( $\mathrm{n}=60)$ from FCCL of the same age were assigned randomly to conventional and flash-freezing methods. In the conventional method, individual whole fish $(n=30)$ were fixed in $10 \%$ neutral buffered formalin for one week. At the end of the week, necropsy was performed during which gills, liver, and gonads were removed and placed in a tissue cassette in $10 \%$ neutral buffered formalin for one week. For the flash-freezing method $(\mathrm{n}=30)$, individual fish wrapped in aluminum foil were placed in liquid nitrogen for one week. After one week, necropsies were performed during which the gills, liver, and gonads were excised from each fish, placed into tissue cassettes, and fixed in 10\% neutral buffered formalin for one week. The tissues from both methods (fresh fixed vs. frozen fixed) were then dehydrated in graded ethanol series, embedded in paraffin, sectioned at $3 \mu \mathrm{m}$, stained with Hematoxylin \& Eosin (H\&E), dried, and coversliped (for more detailed methods see Teh et al., 1997). Fresh and frozen tissues were examined using essential criteria for analyzing histologic features including: 1) tissue architecture and integrity, 2) fixation quality, 3) cellular detail and resolution such as appearance of nuclei, nucleoli, and cell membranes, and 4) staining quality of tissues using a BH-2 Olympus microscope. In addition, one whole wild juvenile Delta Smelt was collected and processed to demonstrate the applicability of the flash-freezing method to a Delta Smelt collected and frozen in the field (for further examples of histopathology of flash-frozen wild fish see Hammock et al. 2015).

\subsubsection{Oocyte morphology in histological sections}

Oocyte structure was assessed in fresh and frozen ovarian sections to determine differences in oocyte shape, integrity of cortical alveoli, and appearance of egg yolk bodies at the 
vitellogenic stage. Earlier descriptions of oocyte stages in Delta Smelt were followed according to Mager (1996) and Kurobe et al. (in revision)

\subsection{Oocyte size}

The influence of flash-freezing on size and structure of oocytes was evaluated using ovaries from 5 reproductively mature females. From each fish, masses of oocytes were removed, placed on glass slides (25-59 oocytes/fish), and individual oocytes were photographed. The slides were immediately placed in conical tubes and flash-frozen in liquid nitrogen. Two hours later, the conical tubes were removed and a second photo was taken of each oocyte after defrosting at room temperature. The size of individual oocytes ( $n=199$ from the 5 fish) before and after the cryopreservation in liquid nitrogen was measured using ImageJ software (http://rsbweb.nih.gov/ij/) by setting a micrometer scale, tracing the oocyte, and then calculating its area using a computational equation in the software. The mean size of the oocytes before and after freezing was compared using a paired t-test.

\subsection{Application of flash-freezing for preserving Delta Smelt collected in the field}

This section describes the use of flash-freezing for preserving smelt following collection in the field and then evaluated for 8 different biological endpoints in the laboratory. While the results of these endpoints are not discussed in this paper, the description aims to emphasize the rationale for using flash-freezing for preserving large numbers of fish collected across multiple sites. During trawl sampling in the San Francisco Estuary (SFE), fish that are captured across locations and identified as Delta Smelt are individually wrapped with aluminum foil, assigned an ID number, and placed in liquid nitrogen immediately. The entire process (identification, wrapping, and freezing) typically takes $5 \mathrm{~min}$, although it can take up to $15 \mathrm{~min}$ if many fish are caught or field conditions are difficult. Delta Smelt are kept in liquid nitrogen continuously until the fish are processed at the Aquatic Health Program at the University of California, Davis using staggered necropsies. During necropsies, fish are removed from liquid nitrogen, fork length (FL) and body weight (BW) are measured, and then multiple organs are immediately excised and preserved for 8 different biological endpoints: 1) otolith for aging and microchemistry, 2) fins for genetic analysis, 3) brain, gill, and liver in liquid nitrogen for enzyme analysis, 4) muscle in liquid nitrogen for nutritional analysis, 5) kidney and spleen in buffered solution for pathogen 
analysis, 6) gills, liver, and gonads in fixative for histology and reproduction, 7) gastrointestinal tract for gut content analysis, and 8) carcass for body burden analysis. The entire necropsy procedure takes 5-10 min per fish. Of these endpoints, the methods for analyzing enzyme, pathogens, and histology using flash-frozen tissues are novel or unconventional. Hence, the equivalence of these methods was evaluated in the current study by comparing measurements made from fresh to flash-frozen samples using hatchery raised Delta Smelt, as described above. To demonstrate the suitability of the freezing method for field samples, photographs of one Delta Smelt that was collected and flash-frozen in the SFE and processed in the lab for histopathology was included.

\section{Results}

\subsection{Morphometry}

Fork length, body weight and condition factor of fresh and flash-frozen Delta Smelt are shown in Table 1. Paired t-tests showed that there were significant differences for fork length $(\mathrm{df}=9, \mathrm{P}=0.004)$, body weight $(\mathrm{df}=9, \mathrm{P}=0.003)$, and condition factor $(\mathrm{df}=9, \mathrm{P}=0.02)$. On average, the percent changes of fork length was $0.55 \%$ and body weight was $0.21 \%$ lower in flash-frozen than in fresh tissues while condition factor was $1.5 \%$ higher in flash frozen than in fresh tissues (Table 1). We found strong, linear relationships between frozen and fresh in fork length (linear regression, $\mathrm{df}=8, \mathrm{P}<0.001, \mathrm{R}^{2}=0.99$ ), body weight (linear regression, $\mathrm{df}=8, \mathrm{P}<0.001, \mathrm{R}^{2}=0.99$ ), and condition factor (linear regression, $\mathrm{df}=8, \mathrm{P}<0.001, \mathrm{R}^{2}=0.97$ ). The regression equation for fork length, body weight, and condition factor are Fresh $=2.558+0.972$ Frozen (fork length), Fresh $=0.00955+0.999$ Frozen (body weight), Fresh $=0.0416+0.933$ Frozen (condition factor), where Fresh is measurement in fresh tissue and Frozen is measurement in frozen tissue.

\subsection{Enzyme activities}

Enzymatic activities of fresh and flash-frozen tissues for brain acetylcholinesterase (AChE), liver ethoxyresorufin-0-deethylase (EROD), and gill sodium-potassium adenosinetriphosphatase (ATPase) activity are shown in Table 2. There were no significant differences in $\mathrm{AChE}$ (paired t-test, $\mathrm{df}=9, \mathrm{P}=0.15$ ) and EROD (paired t-test, $\mathrm{df}=9, \mathrm{P}=0.86$ ) activities between fresh and flash-frozen tissue. However, ATPase activity was $13.9 \%$ lower in flash-frozen than in fresh tissues (Table 1, paired t-test, $\mathrm{df}=8, \mathrm{P}=0.025$ ). We found a strong, 
linear relationship between frozen and fresh ATPase activity (linear regression, $\mathrm{df}=7, \mathrm{P}=0.0025$, $\mathrm{R}^{2}=0.85$ ). The regression equation is Fresh $=0.5336+0.9734$ Frozen, where Fresh is ATPase activity measured in fresh tissue and Frozen is ATPase activity measured in frozen tissue.

\subsection{Pathogen isolation}

The types and number of bacterial colonies, and overall pathogen scores were similar between fresh and 7 -day post frozen tissues after incubation at $15^{\circ} \mathrm{C}$ for 7 days (Table 3). Based on the frequency of occurrence of these bacteria in fresh and frozen tissues, the pathogen scores for all 10 fish were equal between the two treatments: four fish received a pathogen score of 1 in both treatments while six fish received a score of 0 in both treatments. The dominant bacteria that were isolated and identified from spleen and kidney pools of either fresh or frozen smelt include Flavobacterium, Aeromonas, Pseudomonas, Microbacterium, Sphingopyxis, Zooglea, and Bacillus. The presence of these bacteria in the spleen and kidney of smelt was not altered by freezing. Viral agents were not found in either the fresh or corresponding frozen tissues.

\subsection{Histology}

Histological demonstrations of a $3 \mu \mathrm{m}$ thick whole body flash-frozen juvenile smelt (caught in the field) section stained with hematoxylin and eosin (H\&E) are shown in Fig. 1A-G. Morphological details indicate that liver, gill, testis and ovary of all 30 fish were sufficiently preserved and allowed reliable pathological diagnostics. The sections (Fig. 1A-G) are free of distortion with clear resolution of each organ (eye, gill, liver, intestine, pancreas, and immature gonad). Higher magnifications show that the blood cells in the blood vessels of all organs are preserved (Fig. 1B-C). Histological comparison of gill, gonad, and liver tissues that were processed by flash-freezing and conventional fixing techniques are shown in Fig. 2-7.

\subsubsection{Oocyte morphology in histological sections}

Flash-freezing had minimal effects on the internal cellular morphology of oocytes at immature stages (stage 1 and 2, Fig. 6). The presence of nucleolus on the periphery of the nucleus, the characteristic feature of stage 2 oocytes, was not altered (Fig.7A-B). However, artefacts associated with flash-freezing were observed in the gill, liver, and oocytes at mature stages. These included 1) H\&E staining of nucleus and cell membranes of frozen tissues were 
not as distinctly demarcated as the fresh fixed tissue and 2) staining intensity of eosin on erythrocytes in flash-frozen fixed tissues were lighter than that of fresh-fixed tissues (Fig. 2), and 3) separation of interstitial space in gill and 4) intracytoplasmic vacuoles in late stage 3 and 4 oocytes (Fig. 4B, 5B1). At stage 3 late, cortical alveoli ruptured and merged together, forming a transparent large mass located in the center of oocytes dislocating the nucleus toward the periphery (Fig. 6B). Egg yolk bodies at the vitellogenic stage (stage 4) were also ruptured by freezing, leaving traces of yolk bodies in oocytes (Fig. 7 C-D). Freezing also affected the shape of oocytes, especially at the vitellogenic stage; the chorion layer of the oocyte at stage 4 late exhibited an irregular undulating shape in the flash-freezing treatment whereas oocytes from the fresh fish showed an oval or circular shape (Fig. 6B).

\subsection{Oocyte size}

Flash-freezing had a small but significant effect on the size of oocytes (paired t-test, $\mathrm{df}=198, \mathrm{P}<0.0001)$. The mean area of frozen oocytes ( $\mathrm{n}=199$ from 5 fish) was $2 \%$ larger than fresh oocytes. There was a strong, linear relationship between fresh and frozen oocyte area (linear regression, $\mathrm{df}=197, \mathrm{P}<0.0001, \mathrm{R}^{2}=0.75$ ). The regression equation is Fresh $=0.10308+$ 0.82481 Frozen, where Fresh is oocyte area determined from fresh tissue while Frozen is oocyte area determined from frozen tissue.

\section{Discussion}

The San Francisco Estuary is influenced by many covarying environmental impacts. The combined effects of multiple stressors are thought to be causing the general decline of fish abundance in the estuary, particularly the Delta Smelt (e.g. Moyle et al. 1992, Bennett 2005, Sommer et al. 2007). Gaining a better understanding of the causes for the decline of Delta Smelt necessitates a spatially explicit and comprehensive understanding of the health and condition of fish across multiple levels of biological organization and time scales. Moreover, the indices must be sensitive to the many stressors that could be causing the decline such as poor nutrition, contaminants, changing water quality, and disease (Sommer et al. 2007). The current study describes and validates the use of flash-freezing to allow multiple, previously incompatible, indices to be measured on the same fish. However, because freezing fish tissue is not a standard procedure for several of the biomarkers and other endpoints, our study focused on determining 
the compatibility of flash-frozen tissues of Delta Smelt when used with conventional methods for assessing health and condition of fish.

Freezing and fixing in formalin can reduce fish length and weight, however the effect of freezing is minimal compared to formalin preservation (Ogle 2009; Ajah and Nunoo 2003). In this study, although flash-freezing in liquid nitrogen altered the length, weight, and condition factor of Delta Smelt, the percent changes were small. Furthermore, strong linear relationships were observed between fresh and frozen fish in terms of length, weight, and condition factor, providing a method to convert between frozen and fresh measurements.

Flash-freezing of entire Delta Smelt in liquid nitrogen did not affect the activities of EROD in the liver and AChE in the brain, but it did reduce ATPase activity in flash-frozen gill tissues. As ATPase is a membrane bioassay, flash-freezing and thawing may have disrupted the membrane integrity of gills, resulting in lower ATPase activity due to freezing artefacts as shown in Fig. 5B1. However, there was a strong linear relationship between fresh and frozen ATPase activity, providing a method to convert between frozen and fresh measurements. Thus, flashfreezing did not impair our ability to measure the activities of these enzymes.

Using frozen tissues also demonstrated suitable outcomes for isolation of pathogens that commonly use fresh tissues. Bacterial organisms were viable in frozen smelt tissues, and pathogen scores were similar between fresh and flash-frozen tissues. These results suggest that flash-freezing is an appropriate method for preserving field samples of Delta Smelt, (present results, Baxa et al. 2015) to minimize the deterioration of tissues for microbial isolation. Bacterial isolation was compared between fresh and frozen tissues as the standard method requires the use of fresh tissue samples (AFS - Fish Health Section, 2007). Under extenuating circumstances such as in field monitoring surveys, freezing samples can be used to preserve the integrity of fish tissues for isolation of microbial organisms (Noga, 1996; Klinger and FrancisFloyd, 2013). Moreover, our results showed that the bacteria that were recovered in frozen and fresh tissues of smelt were similar in terms of species type (present results; Baxa et al., 2015). Our findings corroborate previous results in other fish species where common bacterial fish pathogens remained viable at 20-60 days post freezing (Brady and Vinitnantharat, 1990). For viral isolation, the World Health Organization (2000) suggests preserving clinical specimens in liquid nitrogen or in -20 or $-70^{\circ} \mathrm{C}$. The absence of viral agents from parallel samples of fresh and frozen tissues of Delta Smelt indicates that viruses were not detectable in either tissue type. 
Overall, we detected no difference in pathogen types and scores between fresh and frozen smelt samples.

Our study demonstrates the advantage of freezing smelt prior to fixation for histological analysis, improving its compatibility with analyses of other biomarkers and endpoints. Although directly preserving the fish in fixative after collection provides standard tissues for histopathology, fixed tissues are no longer useful for the other measurements. For example, formalin-fixed smelt are ideal specimens for evaluating histopathological changes but will no longer be useful for the analyses of enzymatic activities, pathogen isolation, otolith microchemistry, RNA/DNA ratio, and triglycerides. One of the biggest challenges for utilizing flash-frozen tissues is the necessity for histopathologists to be familiarized on evaluating and interpreting lesions and other microscopic changes from frozen samples. Flash-frozen tissues of Delta Smelt revealed good histologic characteristics in gill, gonad, and liver sections based on fundamental criteria, including 1) tissue architecture and integrity, 2) fixation quality, 3) cellular detail and resolution such as appearance of nuclei, nucleoli, and cell membranes, and 4) staining quality of tissues (Fig. 2-4). Despite the cellular changes or tissue artefacts arising from flashfreezing, the key histologic features were observed in frozen sections that allowed us to detect and to distinguish actual alterations such as intracytoplasmic vacuoles in mature oocytes (Fig. 4B) and separation of ionocytes from the interstitial tissue at the base of the primary lamella (Fig. 5B1). These results suggest that flash-freezing whole fish and then preserving in formalin for histopathologic analysis can provide critical information regarding microscopic changes or lesions in Delta Smelt that may develop as an indicator of exposure to stressors as demonstrated in Hammock et al. (2015).

Flash-freezing did not alter the cellular morphology of oocytes at immature stages 1,2 and early stage 3 . However, cryopreservation ruptured the cortical alveoli and egg yolk bodies in later oocyte stages. Oocytes in late stage 3 have the most abundant cortical alveoli that occupy a large area of the oocyte. Ruptured cortical alveoli formed a large mass of cortical alveolus at the center of the oocyte, dislocating the nucleus toward the periphery. Likewise, freezing disrupted the integrity of yolk bodies in stage 4 oocytes. Ruptured yolk bodies merged with each other or with the cytoplasm and lost their circular shape. Despite the freezing artefacts observed in late stage 3 to 4, the maturity level of DS oocytes could be accurately assessed from frozen Delta 378 Smelt. Oocytes at late stage 3 and early stage 4 can be distinguished based on the presence or 
absence of egg yolk bodies. To avoid misclassification of maturity stages, we additionally measured oocyte dimensions that help to identify specific stages of oocyte development. We have established ranges of oocyte sizes in each developmental stage. Though statistically significant, there was a strong linear relationship between fresh and frozen oocyte area measurements, so the linear model fit to the frozen and fresh oocyte area data can be used to convert between frozen and fresh measurements.

The fundamental goal of employing flash-freezing is to quickly and effectively preserve fish until tissues can be processed for multiple endpoints that are useful indicators of fish health and condition. The advantages of flash-freezing smelt samples are that: 1) a wider range of biomarkers and biological endpoints can be measured on the same fish than with conventional preservation techniques allowing for evaluation and integration of multiple stressor responses, 2) quick preservation minimizes handling and sampling stress thereby maximizing sample integrity for various sensitive endpoints such as enzymatic activities, RNA/DNA ratio, triglycerides, and liver glycogen, 3) dissections and tissue processing can be done in the lab more precisely and rapidly than in the field, 4) the speed of the preservation method ensures that each fish is treated similarly, even if a large number of fish is sampled in a single net. The combination of these advantages allows us to integrate the results of histopathology and determinations of oocyte maturity, pathogens, and enzymatic activities with other biomarkers and indices. Our findings demonstrate that flash-frozen tissues were either similar (EROD, AChE, pathogens, histology) or comparable via linear relationships (ATPase and oocyte size) to analyses of fresh tissues. Thus, the freezing approach allows for a more comprehensive assessment of health and condition of an individual fish than with fixed tissues that can only offer a limited number of endpoints. In addition, the use of enzyme and immunohistochemistry to localize enzymatic biomarkers (e.g., Cytochrome P450s, ATPase, and AChE) on target organs of fish considered too small for biochemistry also becomes available. Together, histopathologic and histochemical biomarkers are effective tools for detecting chronic biological effects of environmental contaminants (Teh and Hinton, 1993, Teh et al., 1999; Tay et al., 2003). This study highlights the benefits of fish tissue preservation using flash-freezing to augment the range of data and information that can be generated from an individual fish. Freezing artefacts should not deter a trained histopathologist to distinguish actual cellular morphology. It should be noted that other than an experienced histopathologist, a competent histotechnician plus a standardized method for processing, 
orientation, sectioning, and staining of flash-frozen tissues are highly recommended to minimize artefacts that lead to misdiagnoses of lesions (Wolfe et al. 2014).

It is important to note that the underlying objective of this paper is to evaluate the use flash freezing for preserving and maximizing the use of multiple tissues for a suite of biological endpoints on a small endangered fish. The fundamental reason for the comparison between frozen and fresh tissues is to demonstrate and validate the feasibility and compatibility of the freezing method to a method which traditionally employs fresh samples such as those required for histopathology, bacterial isolation, enzymatic activities, including basic fish morphometrics such as fork length and gross weight. In particular, cellular and morphologic details are critical features in histopathology that have been adequately confirmed in frozen tissue sections in our study providing a dependable histopathologic evaluation in Delta Smelt.

In summary, the San Francisco Estuary is among the most altered ecosystems worldwide (Glibert 2010, Mount et al. 2012), requiring that condition assessments be sensitive to a suite of potential stressors. By adopting a holistic and versatile method of freezing field samples, a flashfreezing approach can integrate multiple biomarkers and biological endpoints addressing a critical need for information on the impacts of stressors such as contaminants, pathogens, food limitation, and changing physicochemical conditions (e.g., Hammock et al. 2015). Over time, the baseline information based on endpoints generated from individual frozen samples, as examined in the current study, will serve as the groundwork for assessing future changes on the overall health of Delta Smelt in the San Francisco Estuary. Flash-freezing could be used in other fish condition assessments for which a wide range of biological endpoints need to be combined with histopathological analysis.

\section{Acknowledgements}

Funding for this study was provided by the California Department of Fish and Wildlife Ecosystem Restoration Program E1183004, U.S. Geological Survey G12AC20079 and G15AS00018, and U.S. Bureau of Reclamation Contract R13AP20021. We would like to thank Gary Wu, Diana Le, Georgia Ramos, and Ching Teh at the Aquatic Health Program for sample processing and histological preparation. We also thank the staff at California Department of Fish and Wildlife especially Randall Baxter for their time, expertise and for entrusting us with the fish, the scientists, and managers of the Interagency Ecology Program for facilitating the project. 
441 Table 1. Comparison of fork length, body weight, and condition factor in fresh and flash-frozen 442 tissues of Delta Smelt.

\begin{tabular}{|c|c|c|c|c|c|c|}
\hline Fish & \multicolumn{2}{|c|}{ Length } & \multicolumn{2}{c|}{ Body Weight } & \multicolumn{2}{c|}{ Condition Factor (K) } \\
\hline & Fresh & Frozen & Fresh & Frozen & Fresh & Frozen \\
\hline 1 & 85.87 & 85.56 & 5.5595 & 5.5497 & 0.8780 & 0.8860 \\
\hline 2 & 71.80 & 70.74 & 3.1026 & 3.0937 & 0.8382 & 0.8739 \\
\hline 3 & 84.56 & 84.16 & 4.4647 & 4.4608 & 0.7384 & 0.7483 \\
\hline 4 & 76.20 & 75.71 & 4.3928 & 4.3855 & 0.9928 & 1.0106 \\
\hline 5 & 76.31 & 76.14 & 3.2842 & 3.2762 & 0.7391 & 0.7422 \\
\hline 6 & 77.24 & 77.21 & 3.6148 & 3.6087 & 0.7844 & 0.7840 \\
\hline 7 & 72.54 & 71.56 & 3.0338 & 3.0389 & 0.7948 & 0.8293 \\
\hline 8 & 77.50 & 77.04 & 3.2277 & 3.2207 & 0.6934 & 0.7044 \\
\hline 9 & 71.53 & 71.39 & 2.6677 & 2.6497 & 0.7289 & 0.7282 \\
\hline 10 & 76.37 & 76.22 & 3.5401 & 3.5256 & 0.7947 & 0.7962 \\
\hline Mean \pm SE & $76.99 \pm 1.54$ & $76.57 \pm 1.58$ & $3.69 \pm 0.28$ & $3.68 \pm 0.28$ & $0.80 \pm 0.25$ & $0.81 \pm 0.26$ \\
\hline
\end{tabular}

444 Condition factor $(K)=\mathbf{1 0}^{5}$. Body Weight $/$ Fork length ${ }^{3}$ 
Table 2. Comparison of enzyme activities in fresh and flash-frozen tissues of Delta Smelt.

446 Tissues were flash-frozen in liquid nitrogen and then stored at $-80^{\circ} \mathrm{C}$ for one week prior to

447 enzyme analysis; fresh tissues were analyzed immediately after the fish were sampled.

\begin{tabular}{|c|c|c|c|c|c|c|}
\hline Fish & $\begin{array}{c}\text { Fresh } \\
\text { EROD }\end{array}$ & $\begin{array}{c}\text { Frozen } \\
\text { EROD }\end{array}$ & $\begin{array}{c}\text { Fresh } \\
\text { AChE }\end{array}$ & $\begin{array}{c}\text { Frozen } \\
\text { AChE }\end{array}$ & $\begin{array}{c}\text { Fresh } \\
\text { ATPase }\end{array}$ & $\begin{array}{c}\text { Frozen } \\
\text { ATPase }\end{array}$ \\
\hline 1 & 0.155 & 0.120 & 14.65 & 14.99 & 2.63 & 2.28 \\
\hline 2 & 0.075 & 0.068 & 15.31 & 14.79 & 3.97 & 3.54 \\
\hline 3 & 0.029 & 0.024 & 21.35 & 21.17 & 2.36 & 2.15 \\
\hline 4 & 0.037 & 0.030 & 20.00 & 18.30 & 3.82 & 2.23 \\
\hline 5 & 0.212 & 0.194 & 20.60 & 17.30 & 2.63 & 2.28 \\
\hline 6 & 1.341 & 1.419 & 18.45 & 20.77 & 5.95 & 5.14 \\
\hline 7 & 0.025 & 0.018 & 14.43 & 13.25 & 1.62 & 1.17 \\
\hline 8 & 0.297 & 0.321 & 19.79 & 19.81 & 4.57 & 4.68 \\
\hline 9 & 0.020 & 0.026 & 18.27 & 16.16 & 2.23 & 2.19 \\
\hline 10 & 0.158 & 0.146 & 26.02 & 24.82 & NA & NA \\
\hline Mean \pm SE & $0.235 \pm 0.12$ & $0.237 \pm 0.13$ & $18.89 \pm 1.12$ & $18.14 \pm 1.12$ & $3.31 \pm 0.41$ & $2.85 \pm 0.43$ \\
\hline
\end{tabular}

EROD: ethoxyresorufin-0-deethylase (pmoles/mg/min) in liver

AChE: acetylcholinesterase ( $\mu$ moles $/ \mathrm{mg} / \mathrm{min})$ in brain

ATPase: sodium $\left(\mathrm{Na}^{+}\right) /$potassium $\left(\mathrm{K}^{+}\right)$adenosinetriphosphatase ( $\mu$ moles/pi/hr/mg protein) in gill 


\begin{tabular}{|l|c|c|c|c|c|c|c|c|}
\hline $\begin{array}{l}\text { Fish } \\
\text { number }\end{array}$ & \multicolumn{2}{|c|}{$\begin{array}{l}\text { Blood Agar } \\
\text { General isolation }\end{array}$} & \multicolumn{2}{c|}{$\begin{array}{c}\text { Tryptone Yeast } \\
\text { Extract (TYES) } \\
\text { Flexibacteria }\end{array}$} & \multicolumn{2}{c|}{$\begin{array}{c}\text { MiddleBrook 7H10 } \\
\text { Mycobacteria }\end{array}$} & \multicolumn{2}{c|}{$\begin{array}{c}\text { Overall } \\
\text { Pathogen Score }\end{array}$} \\
\hline & Fresh & Frozen & Fresh & Frozen & Fresh & Frozen & Fresh & Frozen \\
\hline 1 & 1 & 1 & 3 & 2 & 0 & 0 & 1 & 1 \\
\hline 2 & 0 & 0 & 1 & 1 & 0 & 0 & 1 & 1 \\
\hline 3 & 0 & 0 & 0 & 0 & 0 & 0 & 0 & 0 \\
\hline 4 & 0 & 0 & 0 & 0 & 0 & 0 & 0 & 0 \\
\hline 5 & 0 & 0 & 0 & 0 & 0 & 0 & 0 & 0 \\
\hline 6 & 0 & 0 & 0 & 0 & 0 & 0 & 0 & 0 \\
\hline 7 & 0 & 0 & 2 & 2 & 0 & 0 & 1 & 1 \\
\hline 8 & 0 & 0 & 0 & 0 & 0 & 0 & 0 & 0 \\
\hline 9 & 0 & 0 & 2 & 2 & 0 & 0 & 1 & 1 \\
\hline 10 & 0 & 0 & 0 & 0 & 0 & 0 & 0 & 0 \\
\hline
\end{tabular}

Number of colonies $/ 50 \mu \mathrm{l}$ of tissue homogenate for each type of culture plate using fresh or frozen tissue, and the overall pathogen score. Pathogen Score: 0=absence of bacterial growth; $1=$ minimal number of colonies $(\mathrm{N}=1-10) ; 2=$ moderate number of colonies $(\mathrm{N}=11-20) ; 3=$ high number of colonies $(>21-200) ; 4=$ colonies are too numerous to be counted $(>201)$. Pathogen scores were assigned based on the range of colony numbers that grew on plates. 


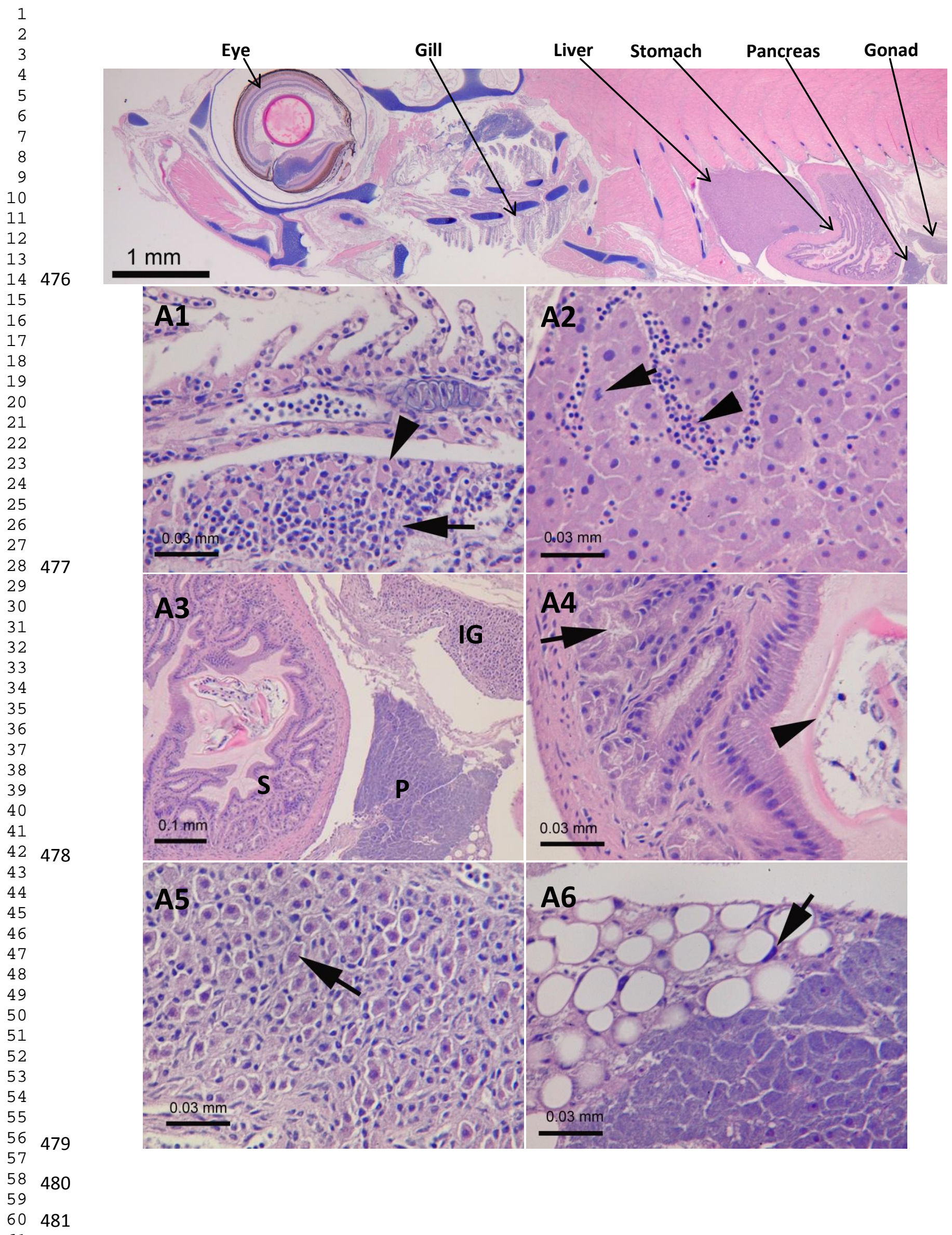


Fig. 1. Flash-frozen juvenile Delta Smelt from the San Francisco Estuary: A1-A6 show the respective organs indicated in Fig. 1 at higher magnification. (A1) gill showing ionocytes (arrowhead) and proliferation of epithelial cells (arrow). (A2) liver showing a mitotic figure (arrow) and blood cells in sinusoid (arrowhead). (A3) stomach (S), pancreas (P) and immature gonad (IG). (A4) higher magnification of A3 showing the gastric gland (arrow) and copepod (arrowhead) in the stomach. (A5) higher magnification of A3 showing primodial germ cell (arrow) of immature gonad, and (A6) higher magnification of A3 showing pancreas (P) and adipose tissue or fat cell (arrow). The fish was frozen in liquid nitrogen for one week, fixed in $10 \%$ neutral buffered formalin for another week, and sections were stained with Hematoxylin and $\operatorname{Eosin}(\mathrm{H} \& \mathrm{E})$. 

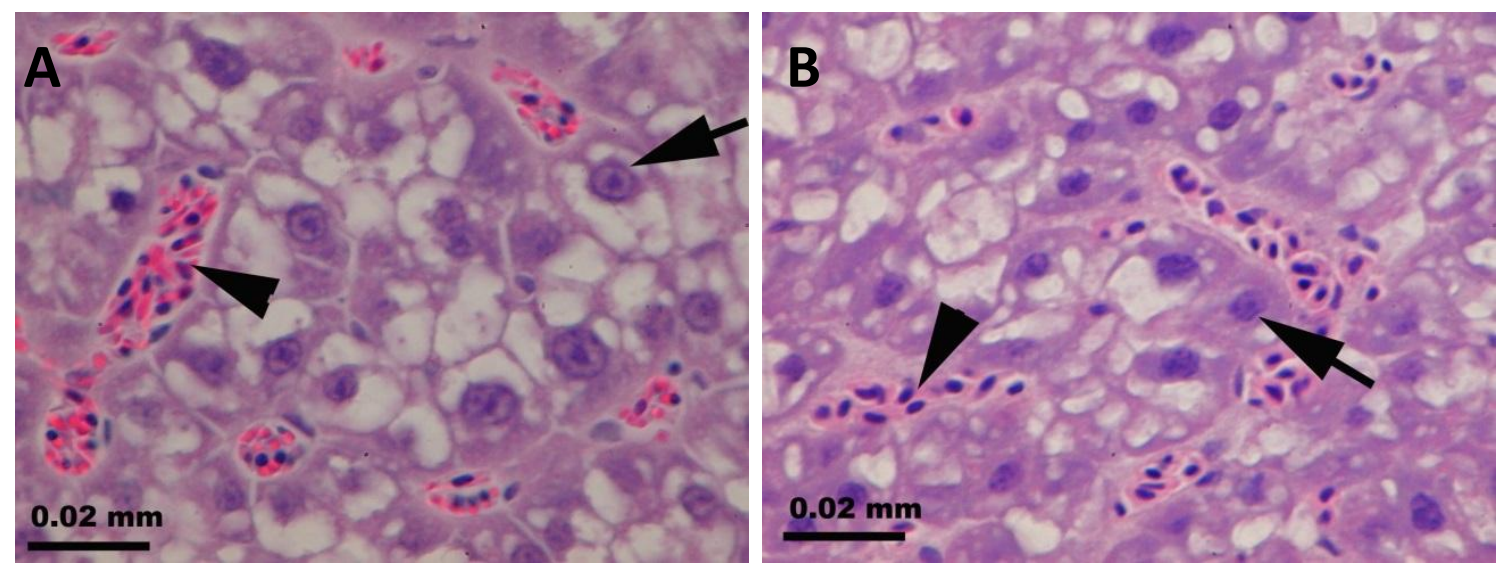

Fig. 2. Sections of fresh (A) and flash-frozen (B) formalin fixed liver of Delta Smelt. Note that staining characteristic of erythrocyte (arrowheads) and cellular detail of nuclei and nucleoli (arrows) are more prominent in fresh-fixed than flash-frozen fixed liver. The fish was frozen in liquid nitrogen for one week, fixed in $10 \%$ neutral buffered formalin for another week, and sections were stained with H\&E. 

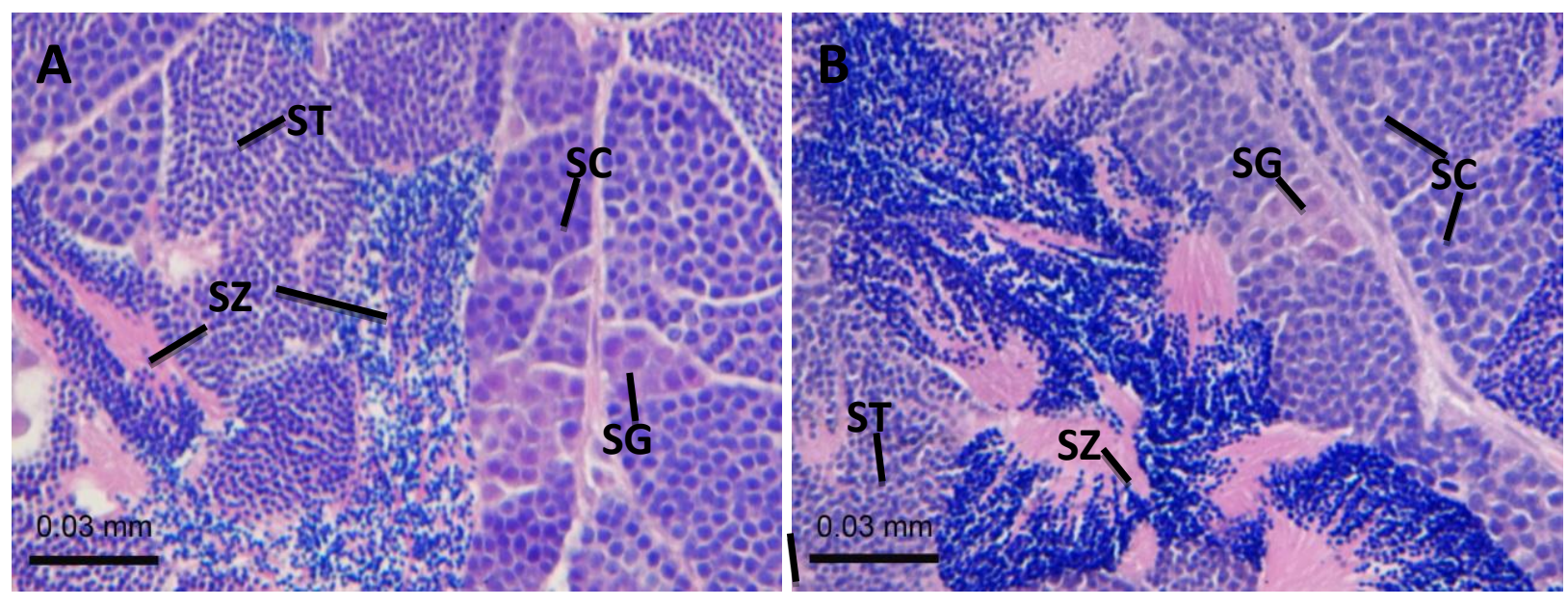

Fig. 3. Fresh (A) and flash-frozen (B) formalin fixed mature Delta Smelt testis. Various stages of spermatogenesis are shown. $\mathrm{SG}=$ spermatogonia, $\mathrm{SC}=$ spermatocytes, $\mathrm{ST}=$ spermatids, $\mathrm{SZ}=$ Spermatozoa. The fish was frozen in liquid nitrogen for one week, fixed in $10 \%$ neutral buffered formalin for another week, and sections were stained with $\mathrm{H} \& \mathrm{E}$. 

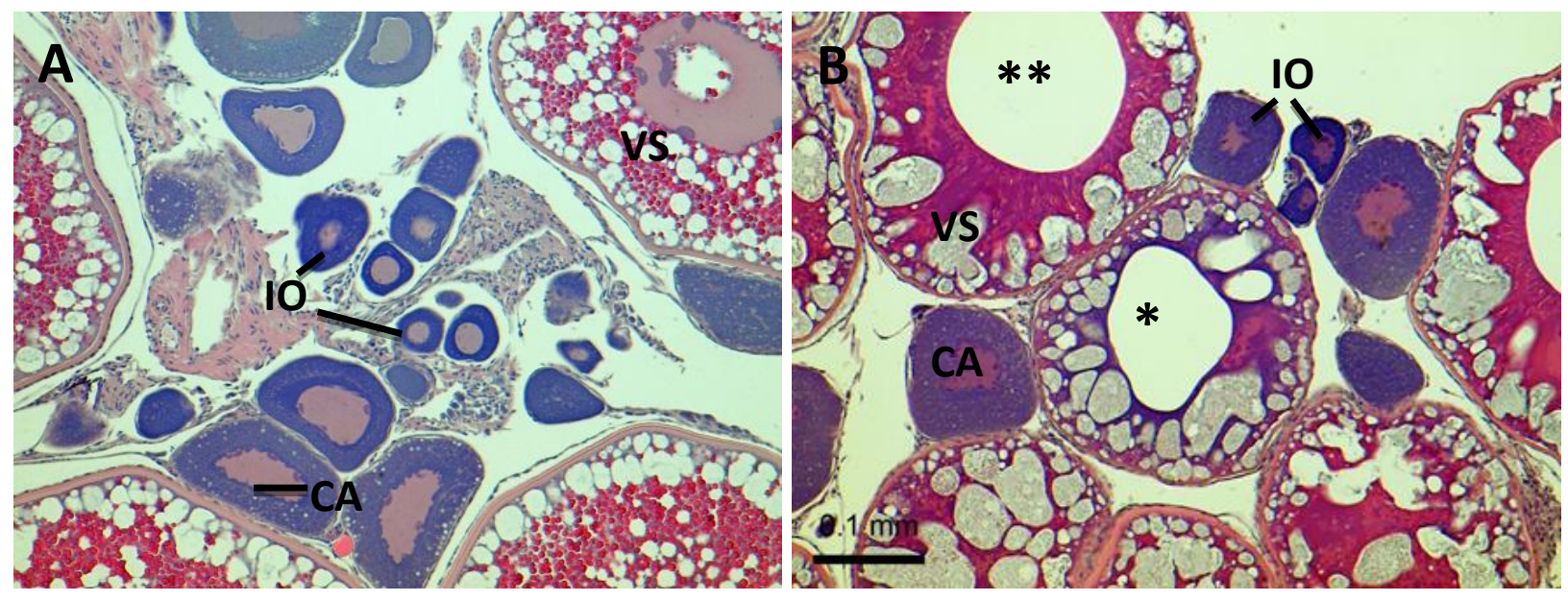

Fig. 4. Fresh (A) and flash-frozen (B) formalin fixed ovary, H\&E-stained sections. Various stages of oogenesis are shown. $\mathrm{IO}=$ stage 1 and 2 immature oocyte, $\mathrm{CA}=$ early cortical alveoli stage $3, \mathrm{VS}=$ vitellogenic stage 4 . Note formation of large vacuoles in late stage $3(*)$ and stage $4(* *)$ in Fig. 4B. Individual oocytes were measured before (fresh) and after a 2-hour cryopreservation in liquid nitrogen. 


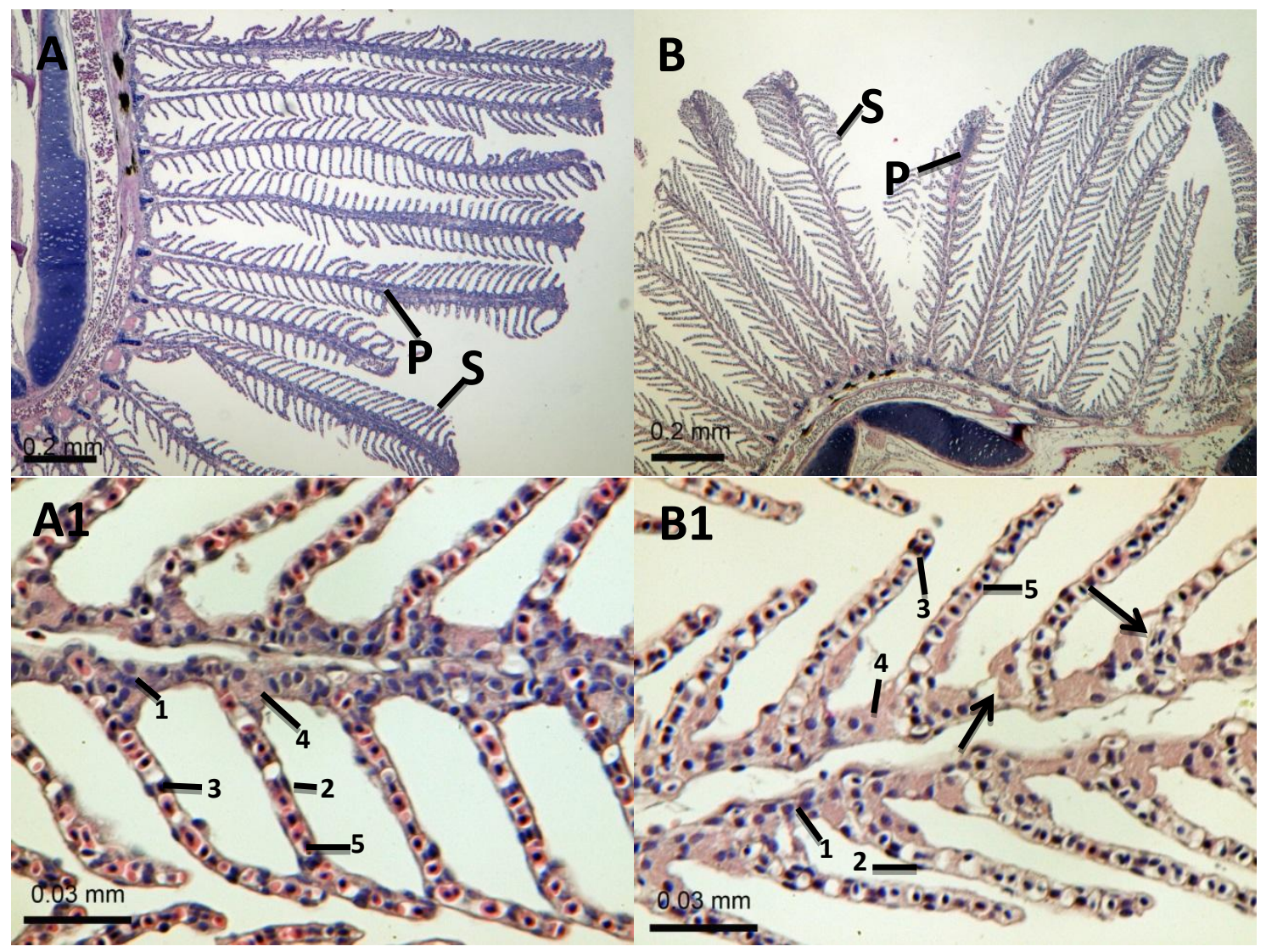

Fig. 5. Fresh (A) and flash-frozen (B) formalin fixed Delta Smelt gill showing the primary (P) and secondary (S) lamellae. A1 and B1 show the respective primary and secondary lamellae indicated in $\mathrm{A}$ and $\mathrm{B}$ at higher magnification. 1 = undifferentiated basal cell, 2 = epithelial cell, 3 $=$ pillar cell, $4=$ ionocyte, and $5=$ erythrocyte. Note: arrows point to a noticeable gap between ionocyte and interstitial tissue at the base of primary lamella, a sign of a freezing artefact. The fish was frozen in liquid nitrogen for one week, fixed in $10 \%$ neutral buffered formalin for another week. Sections were stained with H\&E. 


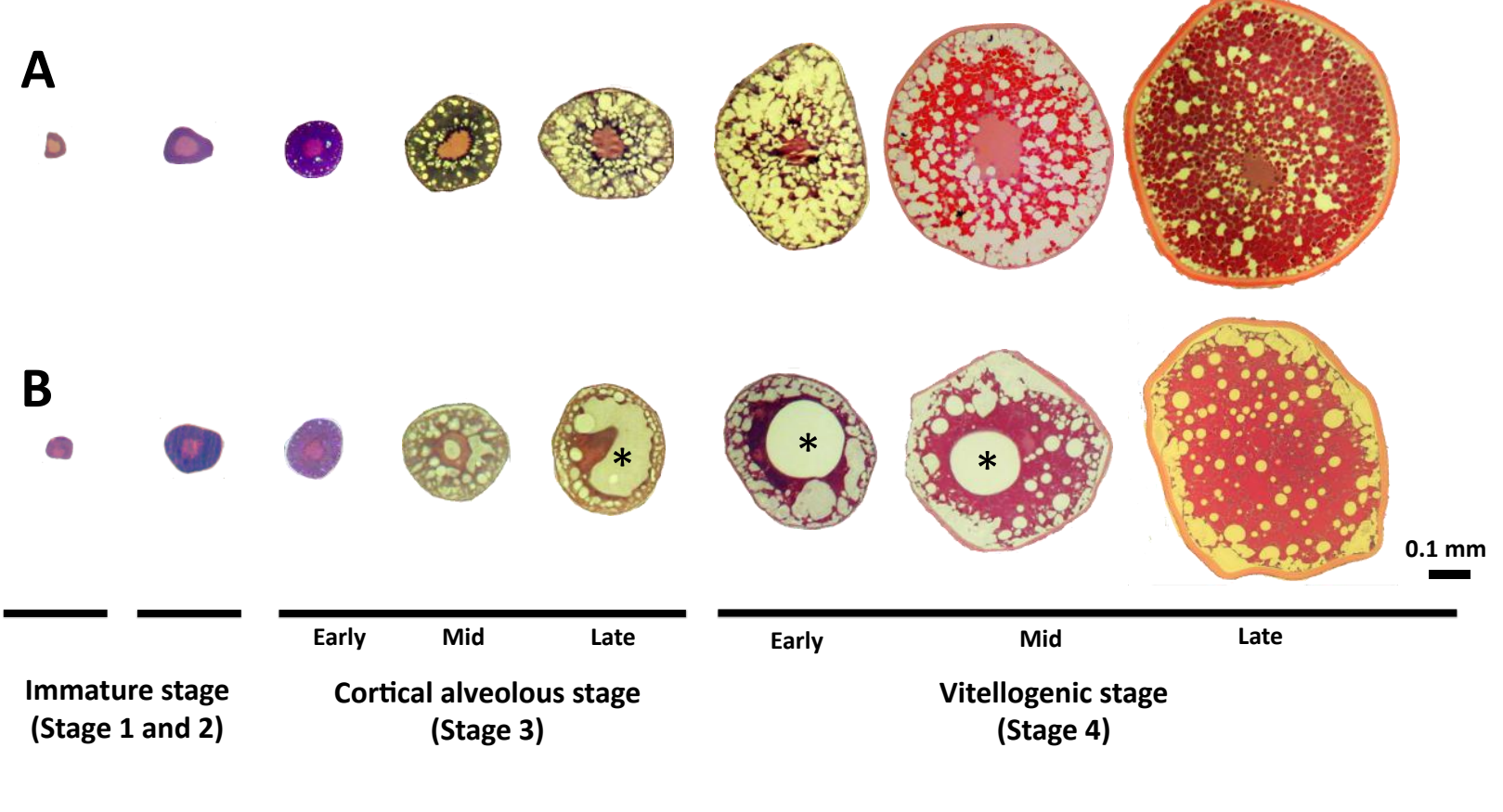

597 Fig. 6. Developmental stages of Delta Smelt oocytes. (A): Oocyte stages from freshly fixed fish 598 without freezing; (B): Oocyte stages from flash-frozen fixed fish. The internal structure of Delta 599 Smelt oocytes at immature stages 1 and 2 was not altered by freezing while stages 3 and 4 600 showed disrupted cortical alveoli and egg yolk bodies (B). The cortical alveoli ruptured and 601 merged together, resulting in dislocation of the nucleus toward the periphery at late stage 3 602 through mid-stage 4 (asterisks). Freezing also affected the shape of oocytes at the vitellogenic 603 stage: the chorion layer of late Stage 4 oocyte exhibited an irregular, undulating shape whereas 604 oocytes from the fresh fixed fish showed an oval or circular shape. Sections were stained with 605 H\&E. 

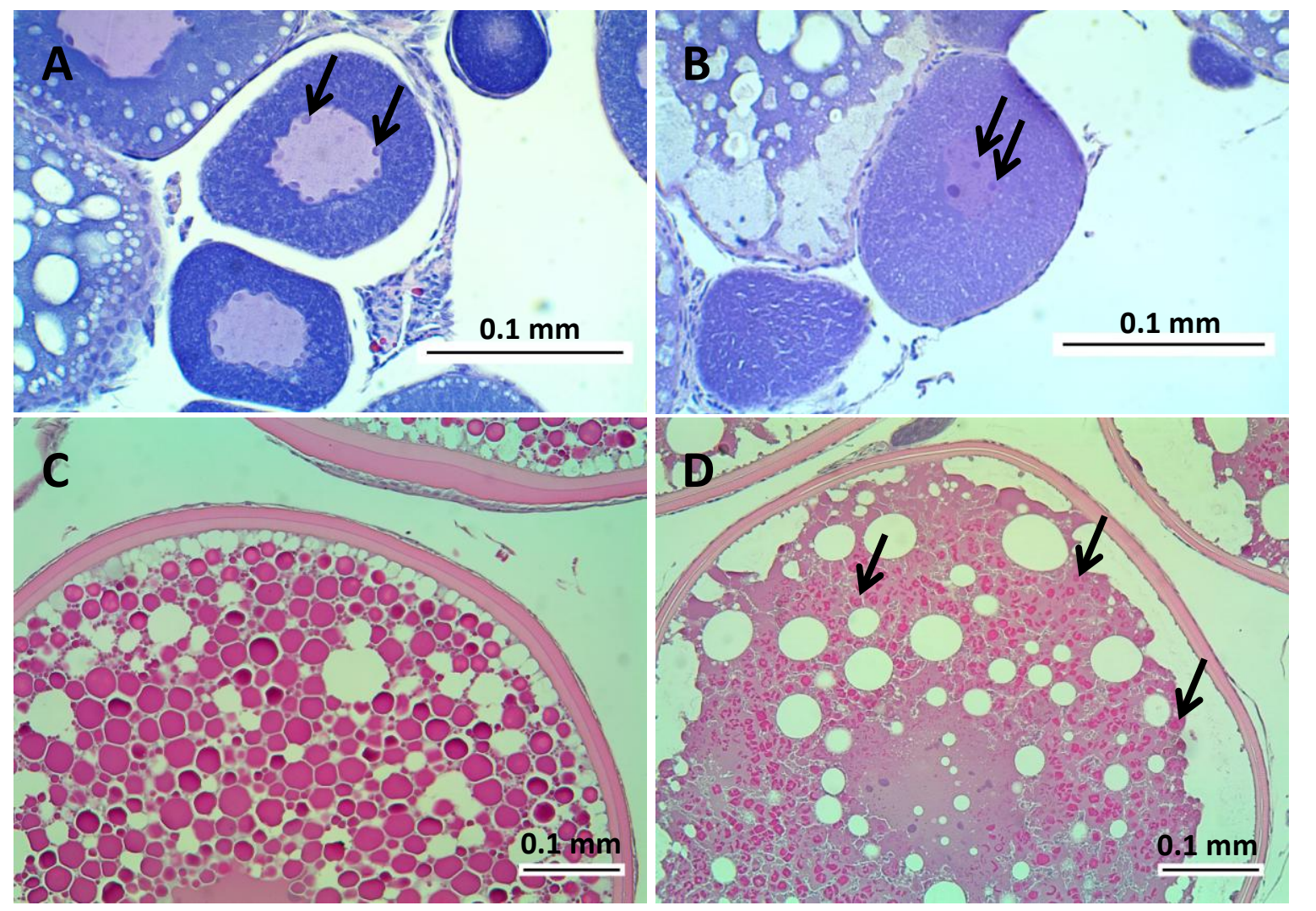

Fig. 7. Internal structure of Delta Smelt oocytes at early stage $2(\mathbf{A}, \mathbf{B})$ and late stage 4 (C, D).

Note that the 2-hour cryopreservation in liquid nitrogen of individual oocytes $(\mathbf{B}, \mathbf{D})$ caused the egg yolk bodies to rupture and merge together, leaving traces of yolk bodies in the cytoplasm of the oocytes as indicated by arrows (D). The internal structure of early stage 2 (arrows) was not altered before and after cryopreservation in liquid nitrogen (A, B). Sections were stained with $\mathrm{H} \& \mathrm{E}$. 


\section{References}

Adams SM, Shepard KL, Greeley MS, Jimenez BD, Ryon MG, Shugart LR. 1989. The use of bioindicators for assessing the effects of pollutant stress on fish. Mar Environ Res 28:459-464.

Adams SM, Greeley MS, Ham KD, LeHew RF, Saylor CF. 1996. Downstream gradients in bioindicator responses: Point source contaminant effects on fish health. Can J Fish Aquat Sci $53: 2177-2187$.

Adams SM, Bevelhimer MS, Greeley MS, Levine DA, Teh SJ. 1999. Ecological risk assessment in a large reservoir: 6. Bioindicators of fish population health. Environ Toxicol Chem 18:628-640.

Ajah PO and Nunoo FKE. 2003. The effects of four preservation methods on length, weight and condition factor of the clupeid Sardinella aurita Val. 1847. J. Appl. Ichthyol. 19: 1-3.

American Fisheries Society - Fish Health Section. 2007. FHS Blue Book: Suggested procedures for the detection and identification of certain finfish and shellfish pathogens. 2007 edn. FHS, Bethesda, Maryland.

652 Baxa DV, Javidmehr A, Mapes SM, Teh SJ. 2015. Subclinical Mycobacterium infections in wild 653 delta smelt. Austin J Vet Sci Anim Husb. 2(1): 1004.

Bennett WA. 2005. Critical assessment of the delta smelt population in the San Francisco Estuary, California. San Francisco Estuary Watershed Sci. 3: 1-73.

http://www.escholarship.org/uc/item/0725n5vk

659 Bevelhimer MS, McManamay RA, O’Connor B. 2014. Characterizing subdaily flow regimes: 660 implications of hydrologic resolution on ecohydrology studies. River Res Appl. doi: $661 \quad 10.1002 /$ rra.2781. 
Brady YJ, Vinitnantharat S. 1990. Viability of bacterial pathogens in frozen fish. J Aquat Anim Health. 2: 149-150.

Burke MD, Mayer RT. 1974. Ethoxyresorufin: Direct fluorimetric assay of a microsomal Odealkylation which is preferentially inducible by 3-methylcholanthrene. Drug Metab Dispos. 2: $583-588$.

California Department of Fish and Wildlife. 2014. State and federally listed endangered and threatened animals of California. California Department of Fish and Wildlife, pp. 1-14.

\section{Cunningham CO. 2002. Molecular diagnosis of fish and shellfish diseases: present status and} potential use in disease control. Aquaculture. 206: 19-55.

Eggens ML, Galgani F. 1992. Ethoxyresorufin- $O$-deethylase (EROD) activity in flatfish: fast determination with a fluorescence plate-reader. Mar Environ Res. 33: 213-221.

Ellman GL, Courtney K, Andres JV, Featherstone RM. 1961. A new and rapid colorimetric determination of acetylcholinesterase activity. Comp Biochem Physiol. 7: 88-95.

Glibert PM. 2010. Long-term changes in nutrient loading and stoichiometry and their relationships with changes in the food web and dominant pelagic fish species in the San Francisco Estuary, California. Rev Fish Sci. 18: 211-232.

Goede RW, Barton BA. 1990. Organismic indices and an autopsy-based assessment as indicators of health and condition of fish. Adams SM, editor. In: Biological Indicators of Stress in Fish. American Symposium 8, American Fisheries Society, Maryland. pp. 93-108.

\section{Hammock BG, Hobbs JA, Slater SB, Acuña S, Teh SJ. 2015. Contaminant and food limitation} stress in an endangered estuarine fish. Sci Total Environ. 532:316-326.

Holliday CW. 1985. Salinity-induced changes in gill NaK-ATPase activity in the mud fiddler 
crab, Uca pugnax: J Exp Zool 199-208.

Huggett RJ, Kimerle RA, Mehrle PM, Bergman HL. 1992. Biomarkers: Biochemical, physiological, and histological markers of anthropogenic stress. Lewis Publishers Inc., Boca Raton, FL. 500 pp.

Johnson LL, Landall JT, Kubin LA, Horness BH, Myers MS, Collier TK, Stein JE. 1998. Assessing the effects of anthropogenic stressors on Puget Sound flatfish populations. J Sea Res 39: $125-137$.

Klinger RE, Francis-Floyd R. 2013. Submission of fish for diagnostic evaluation. http://edis.ifas.ufl.edu, http://edis.ifas.ufl.edu/pdffiles/FA/FA05500.pdf . 706

707 Kurobe T, Park MO, Javidmehr A, Teh FC, Acuña SC, Corbin CJ, Conley A, Bennett WA, Teh 708 SJ. Assessing oocyte development and maturation in the threatened Delta Smelt, Hypomesus 709 transpacificus. Environ Biol Fish (in revision). 710 711 Lowry OH, Farr AL, Randall RJ, Rosebrough NJ. 1951. Protein measurement with the folin 712 phenol reagent. J Biol Chem 193: 265-275.

714 Mager RC. 1996. Gametogenesis, reproduction and artificial propagation of Delta Smelt, 715 Hypomesus transpacificus. Dissertation, University of California. 716

717 Mount J, Bennett W, Durand J, Fleenor W, Hanak E, Lund J, Moyle PB. 2012. Aquatic 718 ecosystem stressors in the Sacramento-San Joaquin Delta. Public Policy Institute of California. 719 720 Moyle PB, Herbold B, Stevens DE, Miller LW. 1992. Life history of delta smelt in the 721 Sacramento-San Joaquin Estuary, California. Trans Am Fish Soc. 121: 67-77. 722 723 Moyle PB. 2002. Inland Fishes of California. The University of California Press, Berkeley, 724 California, USA. 
Myers MS, Johnson LL, Hom T, Collier TK, Stein JE, Varanasi U. 1998. Toxicopathic hepatic lesions in subadult English sole (Pleuronectes vetulus) from Puget Sound, Washington, U.S.A.: relationships with other biomarkers of contaminant exposure. Mar Environ Res 45: 47 - 67.

Noga EJ. 1996. Fish disease diagnosis and treatment. Missouri: Mosby-Yearbook, Inc. Pierce KV, McCain BB, Wellings SR. 1978. Pathology of hepatomas and other liver abnormalities in English sole (Parophrys vetulus) from the Duwamish River Estuary, Seattle, Washington. J Nat Cancer Inst 60: 1445 - 1453.

Ogle DH. 2009. The effect of freezing on the length and weight measurements of ruffe (Gymnocephalus cernuus). Fisheries Research 99: 244-247

737 Sommer T, Armor C, Baxter R, Breuer R, Brown L, Chotkowski M, Culberson S, Feyrer F, 738 Gingras M, Herbold B, Kimmerer W, Mueller-Solger A, Nobriga M, Souza K. 2007. The 739 collapse of pelagic fishes in the upper San Francisco Estuary. Fisheries 32:270-277.

Tay KL, Teh SJ, Doe K, Lee K, Jackman P. 2003. Histopathologic and histochemical biomarker responses of Baltic clam, Macoma balthica to contaminated Sydney Harbour sediment, Nova Scotia, Canada. Environ Health Persp. 111: 273-280.

Teh SJ, Hinton DE. 1993. Detection of enzyme histochemical markers of hepatic preneoplasia and neoplasia in medaka (Oryzias latipes). Aquatic Toxicology, 21: 163-182.

Teh SJ, Adams SM, Hinton DE. 1997. Histopathologic biomarkers in feral freshwater fish populations exposed to different types of contaminant stress. Aquat Toxicol 37:51-70.

Teh SJ, Clark, SL, Brown, C, Hinton, DE. 1999. Enzymatic and histopathologic biomarkers as indicator of environmental contaminant exposure and effect in Asian clam (Potamocorbula amurensis). Biomarker, V4N6: 497-509. 
2

3

762

US Fish and Wildlife Service. 1993. Endangered and threatened wildlife and plants; determination of threatened status for the delta smelt. Federal Register 58:12854-12864.

758 Wolf JC, Baumgartner WA, Blazer VS, Camus AC, Engelhardt JA, Fournie JW, and 12 co759 authors. 2014. Nonlesions, misdiagnoses, missed diagnoses, and other interpretive challenges in 760 fish histopathology studies: a guide for investigators, authors, reviewers, and readers. Toxicol 761 Pathol. 43: 297-325.

763 World Health Organization. Guidelines for the collection of clinical specimens during field 764 investigation of outbreaks. 2000.

765 http://www.who.int/csr/resources/publications/surveillance/WHO_CDS_CSR_EDC_2000_4/en/ 